\title{
A Study on Germination Biology of Wild Mustard (Sinapis arvensis L.)
}

\author{
Bahadır Şin ${ }^{1, a, *}$, İzzet Kadıŏglu ${ }^{1, b}$ \\ ${ }^{1}$ Department Of Plant Protection, Faculty of Agriculture, Tokat Gaziosmanpasa University, 60250 Tokat, Turkey \\ *Corresponding author \\ A R T I C L E I N F O A B S T R A C T \\ Research Article \\ This study has been carried out in 2017-2018 in order to determine seed dormancy and effective \\ germination depth wild mustard (Sinapis arvensis L.). The in-vitro dormancy breaking experiments \\ (tip breaking, sanding, $\mathrm{H}_{2} \mathrm{SO}_{4}$ application, holding in flowing and still water, $\mathrm{GA}_{3}, \mathrm{KNO}_{3}$ and \\ $\mathrm{GA}_{3}+\mathrm{KNO}_{3}$ combination application) has been applied to wild mustard seeds collected from wheat \\ field in Tokat province and has been applied to wild mustard seeds collected from wheat field in \\ Received : 10/11/2020 \\ Accepted : 10/01/2021 \\ Tokat province and the most effective method was determined as 1000 ppm $\mathrm{GA}_{3}+\mathrm{KNO}_{3}$ with $98 \%$ \\ impact on seed germination at $15^{\circ} \mathrm{C}$ within 72 hours. In contrast germination rate has been \\ calculated as $5 \%$ in control plants. Furthermore $15^{\circ} \mathrm{C}$ was assessed as optimum temperature for seed \\ germination was the most effective temperature and during depth studies $100 \%$ of wild mustard \\ Keywords: \\ Wild mustard \\ seeds germinated at $3-5 \mathrm{~cm}$. Because of the difficulies with the work with seeds and plants that have \\ Sinapis arvensis \\ dormancy, these data will contribute future studies.
}

Dormancy

Seedling

Germination

\section{Introduction}

Weeds, that grow in undesired areas, have harmful effect on crop plants and other living things (Özer et al., 2003). Wild mustard (Sinapis arvensis) is an annual plant which damage mainly cereals and field crops as well as several other plants. Wild mustard plant prefer irrigated areas for growth and dense infestations can be found in fields, orchards and pastures (Uygur et al., 1986; Özer et al., 1999).

Weeds compete with crop plants and cause significant yield losses. Weed seeds may contaminate by mix into harvested products and whole plants may contain poisonous substances like mustard oil allyl isothiocyanate. These are harmfull to animal and human health (Cooper and Johnson, 1984; Özer et al., 2003; Direk and Gül, 2003; Güncan and Karaca, 2010). Economic damage threshold of mustard during early stage of wheat has been demonstrated as $0.1 \mathrm{plant} / \mathrm{m}^{2}$ in several studies (Anonymous, 2017). In one of the sudies of Başaran and Kadığlu (2016) economic damage threshold in Tokat has been estimated as 0.67-1.37 plant $/ \mathrm{m}^{2}$. On the other hand, Şin et al. (2016) have carried out a study to identify weeds that mix into harvested wheat in Tokat province and observed intensely mix of weed into wheat. In addition, herbicide resistant wild mustard populations have been detected in several studies conducted in different parts of Turkey (Topuz, 2007; Gürbüz, 2016; Şin and Kadığlu, 2019).

As a result of damage to crop plants weed management has become a priority. It is extremely important to know the biology and ecological requirements of weeds for proper management (Serim and Sözeri, 2011; Şin et al., 2018). This study has been carried out to determine seed dormancy, dormancy breaking methods and optimum germination depths of Sinapis arvensis seeds.

\section{Material and Method}

\section{Material}

Wild mustard seeds used in this study have been collected in 2017 from wheat fields in Tokat Gaziosmanpaşa University experimental area and Tokat Kazova. Mature mustard beans have been collected from plants and seeds have been seperated through sieving, labeled and stored at dark under laboratory conditions. During study $9 \mathrm{~cm}$ diameter glass petri dishes containing filter papers, incubators, domansy breaking chemicals (Gibberellic acid $\left(\mathrm{GA}_{3}\right)$, Potassium nitrate $\left(\mathrm{KNO}_{3}\right)$, Sulfuric acid $\left.\left(\mathrm{H}_{2} \mathrm{SO}_{4}\right)\right)$, nail scissor and sandpaper No:0 have been used. 


\section{Method}

Determination of Optimum Germination Temperature of Wild Mustard (S. arvensis L.)

An experiment was arranged to find optimum germination temperature of freshly collected wild mustard seeds. Studies have been carried out in $9 \mathrm{~cm}$ petri dished and 2-fold Whatman filter paper were placed inside each dish. A total of 25 seeds were placed into each petri dish and about $3 \mathrm{ml}$ sterile water was added to intiate germination. The petri dishes have been stored in incubator at $5,10,15,20,25,30$ and $35^{\circ} \mathrm{C}$ 'and $16 / 8$ (day/night) for 30 days. The experiment has been arranged as randomised plot design with 4 replicates and 2 repeats. The germination has been approved when the plant lenght reached to $0.5 \mathrm{~cm}$ (Uygur and Koch, 1990; Üremiş and Uygur, 1999).

Dormancy Breaking Studies in Wild Mustard ( $S$. arvensis $\mathrm{L}$.)

Dormancy breaking studies of wild mustard ( $S$. arvensis) seeds have been performed based on standart domnacy breaking methods of ISTA (2016). 3 months old wild mustard seeds were used in the experiment. The following methods have been used;

- $\quad$ Soak in Sulphuric acid $\left(\mathrm{H}_{2} \mathrm{SO}_{4}\right)(15,30,45,60,90$, $120 \mathrm{sec} ., 3,5,10,15 \mathrm{~min})$,

- $\quad$ Tip breaking method

- $\quad$ Sand application

- $\quad$ Folding method (7, 15, 30, 50 and 60 days)

- $\quad$ Soak in still water (24, 48 and 72 hours)

- Soak in flowing water (24, 48 and 72 hours)

- Gibberellic acid $\left(\mathrm{GA}_{3}\right)$ application at different doses (500, 750, 1000, 1500 and $2000 \mathrm{ppm}$ ) and with different methods (dipping out, soak and keep in solution, apply with irrigation water).

- $\quad$ Potassium nitrate $\left(\mathrm{KNO}_{3}\right)$ application

- $\quad$ Gibberellic acid $\left(\mathrm{GA}_{3}\right)$ and Potassium nitrate $\left(\mathrm{KNO}_{3}\right)$ application

- Non applied control

The experiment has been arranged as randomised plot design with 4 replicates and 2 repeats. The germination studies have been carried out in $9 \mathrm{~cm}$ petri dished and 2fold Whatman filter paper were placed inside each petri dish in order to create humidity. About $3 \mathrm{ml}$ sterile water was added to each petri dish to intiate germination. During experiments 20 seed were placed into each petri dish. Petri dishes have been stored at $15^{\circ} \mathrm{C}$ 'and $16 / 8$ (day/night) for 30 days. Seeds have been considered to be germinated when the radicule was $2 \mathrm{~mm}$ in length. After the applications, the results were subjected to Tukey test with the SPSS package program and the differences were revealed according to the $\mathrm{P} \leq 0.05$ significance level.

Sulphuric Acid Application $\left(\mathrm{H}_{2} \mathrm{SO}_{4}\right)$

The first step of the study was to arrange the homogenisity of collected seeds by sellection. Before the sulphuric acid application, the selected seeds were separated by 150 for each application and subjected to $96 \%$ suphuric acid $\left(\mathrm{H}_{2} \mathrm{SO}_{4}\right)$ for 15, 30, 45, 60, 90, $120 \mathrm{sec}$., 3, 5, 10, 15 minutes. After applications seeds were sieved through iron sieve and washed totally with tap water.

\section{Tip Breaking Method}

In this method small cutting was opened on seed coat with nail scissor without damaging embryos. Cutted seeds were transferred to incubator and stored.

\section{Sanding Method}

Sanding, a method that is generally applied to plants with thin seed coat, have been used in this study to asess the impact of seed coat on dormancy. Using water sandpaper, no $=0$ wild mustard seed coats were scratched in order to evaluate the effect of coat.

\section{Folding Method}

Folding have been applied in order to determine the vernalisation requirement of wild mustard seeds. In this method wild mustards seeds have been placed on wetted filter papers and covered with another and then moistured with water to create humidity. This humid growth areas have been stored at $+4^{\circ} \mathrm{C}$ in the dark for $7,15,30,50$ and 60 days, then $-18^{\circ} \mathrm{C}$ for 7 and 15 days and at last kept in incubator for 30 days.

\section{Soak in Still Water}

Due to difficult permeability of seed coats the wild mustard seeds have been soaked in distilled water for 24 , 48 and 72 hour and at the end of this period seeds have been sieved in order to discard water and then kept on sterile filter paper.

\section{Soak in Flowing Water}

Some plant seeds contian chemicals which prevent seed germination. A study has been carried out with mustard seeds to evaluate if the germination was prevented by this kind of substances. On this purpose wild mustard seeds have been soaked in to flowing water for 24,48 and 72 hours.

Gibberelic Acid $\left(G_{3}\right)$ Application

Gibberelic acid $\left(\mathrm{GA}_{3}\right)$ is responsible for inducing embryo growth. After $\mathrm{GA}_{3}$ application endo- $\beta$-mannanaz secretion produced in endosperm disrupts cell wall to promote germination (Yamaguchi and Kamiya, 2002). In our study $3 \mathrm{ml}$ of $\mathrm{GA}_{3}$ at different concentrations $(500,750$, 1000, 1500 and $2000 \mathrm{ppm}$ ) have been applied to each petri dishes. In addition, wild mustard seeds have been treated with $\mathrm{GA}_{3}$ by dipping out for 3, 5 and $10 \mathrm{~min}$. and soaking in solution for 12, 24, 48 hours. At the end of this period seeds have been sieved in order to discard water and dried. Dried seeds have been placed onto petri dishes and stored in incubator at $15^{\circ} \mathrm{C}$ for 1 month.

\section{Potassium Nitrate $\left(\mathrm{KNO}_{3}\right)$ Application}

Potassium nitrate has the same effect with $\mathrm{GA}_{3}$ when applied to seeds. In our study $3 \mathrm{ml}$ of potassium nitrate at different concetrations $(500,750,1000,1500$ and 2000 $\mathrm{ppm}$ ) have been applied to each petri dishes.

\section{$\mathrm{GA}_{3}+\mathrm{KNO}_{3}$ Combination}

GA3 + KNO3 was applied at a dose of 1000 ppm by combining the dose of $1000 \mathrm{ppm}$, which obtained the best results of potassium nitrate and glyceric acid applications. The trials have been carried out with similar method of giberellic acid applications.

\section{Germination Study of Wild Mustard Seeds at Different} Depths

A study was carried out to determine maximum germination depth of seeds. In this study five dormancy breaked wild mustard seeds have been sowed on each cylindrical pot containing $1 / 3$ sterile peat and soil. The seeds have been sowed at different depths including 3, 5 , 7,12 ve $15 \mathrm{~cm}$ and pots were kept in incubator at $15^{\circ} \mathrm{C}$ for 21 days. Pots with a depth of $20 \mathrm{~cm}$ were used in the experiment. Plants emerging on the soil surface are considered to germinate when dicotyledonous leaves are formed. The experiment has been arranged as randomised plot design with 4 replicates and 2 repeats. Emergence depths have been calculated based on aritmetic rate. 


\section{Results and Discussion}

Determination of Optimum Germination Temperature of Wild Mustard Seeds

During germination temperature studies the highest seed germination have been achieved at $15^{\circ} \mathrm{C}(\% 5)$ while none of the seeds germinated at lower temperatures like 0 and $5^{\circ} \mathrm{C}$ as well as higher temperatures like 30 and $35^{\circ} \mathrm{C}$. The germination rate at 10,20 and $25^{\circ} \mathrm{C}$ have been calculated as $2 \%, 3 \%$ and $2 \%$ respectively. Compared to germination breaked seeds the germination of non-treated control seeds were $5 \%$. These findings showed that wild mustard seeds have high dormacy. The same results have been obtained from different studies of researchers. Ateş and Üremiş (2018) collected wild mustard seeds from wheat fields in Şanlıurfa ve Batman and established germination temperature studies with dormancy breaked seeds. In this study the minimum, optimum and maximum germination temperatures have been found as $10,15,25^{\circ} \mathrm{C}$, respectively.

\section{Dormacy Breaking Studies}

The results of dormancy breaking studies have been given in Table 1.

\section{Sulphuric Acid Application}

When Wild mustard seeds stored at $15^{\circ} \mathrm{C} 30$ minutes, the germination have not been achieved at lower storage periods. The most effective result ( $30 \%$ germination) has been obtained from suphuric acid application for 3 to 5 minutes. Several researchers worked on dormancy breaking with sulphuric acid. Güncan (1976) kept wild mustard seeds into concentrated sulphuric acid for 30 minutes and observed $1 \%$ to $9 \%$ germination. Erciş et al. (1993) applied concentrated sulphuric acid for 30 and 60 seconds and 3\% of treated seeds germinated. Akın (2004) achieved $18 \%$ germination with sulphuric acid applied wild mustard seeds. Ateş (2017) carried a study with 12 month and 1 month stored seeds and found the highest germination (91.9\%) in 60 seconds and 12 month stored seeds. In the same study burn and disruption was observed in seeds treated for 30 minutes with sulphuric acid. The impact of plant variety and duration of applications have been addressed in several other studies.

Table 1. The germination percentages of seeds after different germination breaking experiments

\begin{tabular}{|c|c|c|c|}
\hline Application method & Time & Germination $\%$ & Tukey Grup \\
\hline \multirow{10}{*}{ Sulphuric Acid Application } & $15 \mathrm{sec}$ & 0 & $\mathrm{~N}$ \\
\hline & $30 \mathrm{sec}$ & 0 & $\mathrm{~N}$ \\
\hline & $45 \mathrm{sec}$ & 0 & $\mathrm{~N}$ \\
\hline & $60 \mathrm{sec}$ & 5 & M \\
\hline & $90 \mathrm{sec}$ & 10 & JK \\
\hline & $120 \mathrm{sec}$ & 20 & $\mathrm{H}$ \\
\hline & $3 \min$ & 30 & $\mathrm{~F}$ \\
\hline & $5 \mathrm{~min}$ & 30 & $\mathrm{~F}$ \\
\hline & $10 \mathrm{~min}$ & 20 & $\mathrm{H}$ \\
\hline & $15 \mathrm{~min}$ & 10 & $\mathrm{JK}$ \\
\hline Tip Breaking & & 10 & $\mathrm{~J}$ \\
\hline Sanding & & 30 & $\mathrm{~F}$ \\
\hline \multirow{5}{*}{ Folding $\left(+4^{\circ} \mathrm{C}\right)$} & 7 day & 5 & $\mathrm{M}$ \\
\hline & 15 day & 5 & M \\
\hline & 30 day & 5 & M \\
\hline & 50 day & 10 & JKL \\
\hline & 60 day & 10 & $\mathrm{JK}$ \\
\hline \multirow{2}{*}{ Folding $\left(-18^{\circ} \mathrm{C}\right)$} & 7 day & 2 & $\mathrm{MN}$ \\
\hline & 15 day & 0 & $\mathrm{~N}$ \\
\hline \multirow{3}{*}{ Soak in Still Water } & 24 hours & 0 & $\mathrm{~N}$ \\
\hline & 48 hours & 5 & KLM \\
\hline & 72 hours & 0 & $\mathrm{~N}$ \\
\hline \multirow{3}{*}{ Soak in Flowing Water } & 24 hours & 0 & $\mathrm{~N}$ \\
\hline & 48 hours & 5 & M \\
\hline & 72 hours & 5 & LM \\
\hline \multirow{5}{*}{ Giberrelic Acid $\left(\mathrm{GA}_{3}\right)$ Application } & $500 \mathrm{ppm}$ & 50 & $\mathrm{D}$ \\
\hline & $750 \mathrm{ppm}$ & 80 & $\mathrm{~B}$ \\
\hline & 1000 ppm & 97 & A \\
\hline & $1500 \mathrm{ppm}$ & 60 & $\mathrm{C}$ \\
\hline & $2000 \mathrm{ppm}$ & 40 & $\mathrm{E}$ \\
\hline \multirow{5}{*}{ Potassium Nitrate $\left(\mathrm{KNO}_{3}\right)$ Application } & $500 \mathrm{ppm}$ & 10 & IJ \\
\hline & $750 \mathrm{ppm}$ & 15 & I \\
\hline & 1000 ppm & 25 & G \\
\hline & $1500 \mathrm{ppm}$ & 20 & $\mathrm{H}$ \\
\hline & $2000 \mathrm{ppm}$ & 10 & $\mathrm{~J}$ \\
\hline Control & Pure water & 5 & $\mathrm{M}$ \\
\hline $1000 \mathrm{ppm} \mathrm{GA}_{3}+\mathrm{KNO}_{3}$ & & 98 & A \\
\hline
\end{tabular}




\section{Tip Breaking and Sanding}

When tip breaking has been applied to wild mustard seeds germination have been calculated as $10 \%$ while the percentage have been $30 \%$ in sanding. Several studies reveal the effect of tip breaking and sanding. Ateş (2017) sanded 12 months stored seeds and observed $76 \%$ germination. In the same study the rate was $65.8 \%$ in 1 month old seeds. These results have been supported by finding that sanding promote seed germination.

\section{Folding Application}

After several storage conditions germination have been observed in seeds at $-18^{\circ} \mathrm{C}$. On the other hand, the germination rate of seeds stored at $+4^{\circ} \mathrm{C}$ for $7,15,30,50$ and 60 days have been found as 5, 5, 5, 10 and $10 \%$ respectively. Depending on these results increasing effect of longer duration period on germination have been determined.

\section{Soak in Still and Flowing Water}

As seeds soaked in still and flowing distilled water at $24^{\circ} \mathrm{C}$ for 24,48 and 72 hours have been assayed for germination and no effect of distilled water have been observed (Table 1). When Topuz (2007) established the same experiment with seeds resistant or susceptible to chlorosuphuron the germination percentage in resistant and susceptible populations were 71.8-75.0\% and 27.1-31.2\% respectively. In another study Ateş (2017) soaked seeds into distilled water for 6, 24, 48, 72, 96 and 120 hours and the germination percentage were $46.4,26.5,12.5,3.5,3.3$, 2.0 respectively. In that study germination decreased parallel to duration increase.

\section{Gibberellic Acid $\left(\mathrm{GA}_{3}\right)$ Application}

In this study $\mathrm{GA}_{3}$ at different concentrations (500, 750, 1000,1500 and $2000 \mathrm{ppm}$ ) has been applied to wild mustard seeds to determine the effect on germination. The most effective concentration for germination has been found as $1000 \mathrm{ppm} \mathrm{GA}_{3}$ (97\% germination) and the decrease occured when the concentration increased. The highest germination at $1000 \mathrm{ppm}$ application has been observed in 5th day. In addition, the seeds have been soaked in 1000 ppm for 24,48 and 72 hours as well as dipped of for 3, 5 and 10 minutes but germination has not been occured. Erciş et al. (1993), stored seeds for 6 months at room temperature and then treated seeds with $\mathrm{H}_{2} \mathrm{SO}_{4}$ for 30 and 60 seconds and later applied $500 \mathrm{ppm} \mathrm{GA}_{3}$. The germination percentage was found $3 \%$ in only $\mathrm{H}_{2} \mathrm{SO}_{4}$ application and $39 \%$ in $\mathrm{H}_{2} \mathrm{SO}_{4}$ and $\mathrm{GA}_{3}$ combination. Topuz (2007) carried out a study with chlorsulfuron resistant and susceptible seeds and applied $\mathrm{GA}_{3}$ at different concentrations $(0.1,1,5$ and $10 \mathrm{mM})$. In this study the statistical differences were not observed in the point of germination. Ateş (2017) worked with 1 month and 12 months stored seeds and evaluated $2000 \mathrm{ppm} \mathrm{GA}_{3}$ as most effective concetration. The germination percentage with 1 month and 12 months seeds has been determined as $95.7 \%$ and $100 \%$, respectively.

\section{Potassium Nitrate $\left(\mathrm{KNO}_{3}\right)$ Application}

The wild mustard seeds have been treated with different concentrations of potassium nitrate $\left(\mathrm{KNO}_{3}\right)$ for 30 days. The percentage in control plants have been calculated as $5 \%$ while this rate has been found as $25 \%$ in $1000 \mathrm{ppm}$. Goudey et al. (1987) used different chemicals $\left(\mathrm{KNO}_{3}\right.$ and $\mathrm{NH}_{4} \mathrm{Cl}$ ) to break dormancy in seeds and no effect was observed with single application of each chemical but the rate increased to $90 \%$ in chemical combination. Uludağ and Özer (1999) treated seeds with different chemicals $\left(\mathrm{GA}_{3}, \mathrm{KNO}_{3}, \mathrm{H}_{2} \mathrm{SO}_{4}\right)$ as well as applied mechanical methods (scratch) to break dormancy. In $\mathrm{KNO}_{3}$ treatment the germination of Cerastium dichotomum L. seeds were determined as $90 \%$. In other research Ateş (2017) applied $\mathrm{KNO}_{3}$ at concetrations of $0.5,1,3,4 \%$ to 1 - and 12-monthold wild mustard seeds and the germination percentage at $0.5 \%$ concentration were $75.1 \%$ and $47.8 \%$ respectively

At the end of this study the ideal germination rate $(97 \%)$ has been achieved in 1000 ppm $\mathrm{GA}_{3}$ application and irrigation water for 5 days. In order to promote hormonal germination three methods including sanding, 1000 ppm gibberelic acid and $1000 \mathrm{ppm}$ potassium nitrate $+1000 \mathrm{ppm}$ gibberellic acid have been applied together. Sanding+gibberellic acid has caused $92.5 \%$ decrease in the germination while potassium nitrate+gibberellic acid application resulted in $98 \%$ increse.

\section{Seed Germination at Different Soil Depths}

In depth study wild mustard seeds treated with 1000 ppm $\mathrm{GA}_{3}$ and $\mathrm{KNO}_{3}$ for 48 hours to break dormancy have been used. The optimum germination percentage has been achieved as $100 \%$ at 3 and $5 \mathrm{~cm}$ depths. Parallel to increase in depth the germination has decreased. The germination decreased to $75 \%$ at $7 \mathrm{~cm}$ depth and at $12-15 \mathrm{~cm}$ seeds have not been able to emerge to soil surface.

\section{Results}

Wild mustard is an annual Mediterranean plant that is distributed mainly in lentil and sugarbeet fields, gardens and pastures. The higher dormancy level of plant hardens the studies.

It is one of the plants that is difficult to study due to the high rate of dormancy in its seeds. To select the proper management method its essential to know plant biology. The optimum germination temperature of newly collected seeds having dormacy have been determined as $15{ }^{\circ} \mathrm{C}$. During studies with different applications (soak in sulphuric acid for 3-5 minutes, sanding) the germination percentage have been not found as much as $30 \%$. The other application had little effect on dormancy by affecting coat permeability. About $97 \%$ germination has occured at 1000 ppm $\mathrm{GA}_{3}$ application for 5 days. While $98 \%$ observed at 1000 ppm $\mathrm{GA}_{3}+\mathrm{KNO}_{3}$ treatment for 2-3 days. The plant is economically important and the results of studies like this will promote further studies.

\section{References}

Akın B. 2004. Dormansi kırıcı yöntemlerin yabancı ot tohumları üzerinde etkileri. Dumlupınar Üniversitesi Fen Bilimleri Enstitüsü, Yüksek Lisans Tezi, Kütahya.

Anonymus 2017. Buğday Entegre Mücadele Teknik Talimatları. T.C. Gıda, Tarım ve Hayvancılık Bakanlığı, Tarımsal Araştırmalar ve Politikalar Genel Müdürlüğü, Bitki Sağlığı Araştırmaları Daire Başkanlığı, Ankara, 138 sayfa.

Ateş E. 2017. Batman ve Şanlıurfa buğday alanlarında bulunan yabanc1 otlar ile yabani hardal (Sinapis arvensis L.) ve kısır yabani yulaf (Avena sterilis L.)'ın bazı biyolojik özelliklerinin belirlenmesi. Mustafa Kemal Üniversitesi / Fen Bilimleri Enstitüsü, Yüksek Lisans Tezi. 
Ateş E, Üremiş İ. 2018. Sinapis arvensis L. (yabani hardal) ve Avena sterillis L. (kısır yabani yulaf) tohumlarının çimlenme sicaklıklarının belirlenmesi. International Journal of Agricultural and Natural Sciences. Uluslararası Tarım ve Doğa Bilimleri Dergisi. E-ISSEC:2651-3617, 1(2):154-159, 2018.

Başaran B, Kadığlu İ. 2016. Tokat İli Buğday Ekim Alanlarında Sorun Olan Yabani Hardal (Sinapis arvensis L.)'⿺n Ekonomik Zarar Eşiğinin Belirlenmesi. Turk J. Weed Sci, 19(1):1-5.

Cooper MR, Johson AW. 1984. Poisonous plants in Britain and their effects on animals and man. Her Majesty's Stationery Office, London, England. 305 pp.

Direk M, Gül A. 2003. Konya ticaret borsasında buğday fiyat oluşumunu etkileyen faktörler. Ticaret Borsası Dergisi, Sayı: 16 , Konya

Erciş A, Tastan B, Yıldırım A. 1993. Yabani hardal ( $S$. arvensis)'ın bazı biyolojik özellikleri üzerinde araştırmalar. Türkiye I. Herboloji Kongresi (3-5 Şubat1993 Adana) 55-61.

Güncan A. 1976. Erzurum çevresinde bulunan yabancı otlar ve önemlilerinden bazılarının yazlık hububatta mücadele imkanları üzerinde araştırmalar. Atatürk Üni. Yayınları No. 446. Erzurum.

Güncan A. ve Karaca M. 2014. Yabanc1 Ot Mücadelesi (Güncelleştirilmiş ve İlaveli Üçüncü Baskı) Selçuk Üniversitesi Ziraat Fakültesi Yayınları Konya, 310s.

Gürbüz R. 2016. Adana İli Buğday Ekim Alanlarında ALS İnhibitörü Herbisitlere Karşı Dayanıklılık Kazanmış Yabani Yulaf (Avena sterilis L.) ile Yabani Hardal (Sinapis arvensis L.) Popülasyonlarının Belirlenmesi ve Dayanıklılık Haritalarının Oluşturulması. Çukurova Üniversitesi, Fen Bilimleri Enstitüsü, Doktora Tezi. Adana, 372 sayfa.

ISTA, 2016. Rules Proposal Fort the International Rules for Seed Testing, 2016 edition 41s.

Özer Z, Kadığlu İ, Önen H, Tursun N. 2003. Herboloji (Yabanc1 Ot Bilimi). Gaziosmanpaşa Üniversitesi, Ziraat Fakültesi Yayınları No:29, Ders Notları Serisi No:10, 579 sayfa.

Özer Z, Önen H, Tursun N, Uygur N. 1999. Türkiye'nin Bazı Önemli Yabancı Otları (Tanımları ve Kimyasal Savaşımları). Gaziosmanpaşa Üniversitesi Ziraat Fakültesi Yayınları No:38, Kitap Serisi No:16, 434 sayfa.
Serim AT, Sözeri S. 2011. Doğu Tarla Hazeranı [Consolida orientalis (Gay) Schröd. (Ran)]'nın Çimlenme Biyolojisi Üzerinde Araştırmalar. Türkiye Herboloji Dergisi, 14 (1-2):9-16.

Şin B, Kadıŏlu İ. 2019. Amasya, Çorum, Tokat ve Yozgat illerinde buğday yetiştirilen alanlarda Sinapis arvensis (Yabani Hardal) bitkisinin varlığının ve Tribenuron methyl etken maddeli herbisite karşı hassaslığının belirlenmesi. 3 . Uluslararası ÜNIDOKAP Karadeniz Sempozyumu. "Sürdürülebilir Tarım ve Çevre. 21-23 Haziran 2019 Tokat, Türkiye.

Şin B, Kadıŏlu İ, Altuntaş G, Kekeç M, Kazankıran T. 2018. Çeti [Prosopis faracta (Banks\&Sol.) J.F.Mac.] Bitkisinin Tohum Çimlenme Biyolojisinin Araştırılması. Turk J. Weed Sci, 21(1): 53-60.

Şin B, Kadığlu İ, Kamışlı B. 2016. Tokat İlinde Buğday Ürünü İçerisine Karışan Yabancı Ot Tohumlarının Belirlenmesi. Turk J Weed Sci, 2016:19(2): 28 - 37.

Topuz M, 2007. Marmara Bölgesinde Buğday Tarlalarında Bulunan Sinapis arvensis L. (Yabani Hardal)'1n Sulfonylüre Grubu Herbisitlere Karşı Oluşturduğu Dayanıklılık Üzerine Araştırmalar. Ege Üniversitesi Fen Bilimleri Enstitüsü, Doktora Tezi, 202sayfa. İzmir.

Uygur FN, Koch W, Walter H. 1986. Çukurova Bölgesi Buğday, Pamuk Ekim Sistemindeki Önemli Yabancı Otların Tanımı. PLITS, 1986/4 (1): 196s. Vol.2, 379-384.

Uygur FN, Koch W. 1990. Cynodon dactylon L. Pers. ve Sorghum halepense (L.)Pers.'nin Tohumlarının Çimlenmesini ve rizom boğumlarının Sürmesini Etkileyen Faktörlerin Araştırılması. Doğa- Turkish Journal of Agricultural and Forestry, 14:192-201

Üremiş İ, Uygur FN. 1999. Çukurova Bölgesindeki Önemli Bazı Yabancı Ot Tohumlarının Minimum, Optimum ve Maksimum Çimlenme Sıcaklıkları, Türkiye Herboloji Dergisi, 2 (2): 1-12.

Yamaguchi S, Kamiya Y. 2002. Gibberalins and Light-stimulated Seed Germination. J. Plant Growth Regul, 20:369-376. 